\title{
Architecture_MPS
}

\section{Toronto's Smart City: Everyday Life or Google Life?}

T F Tierney ${ }^{1, *}$

How to cite: Tierney, T. F. 'Toronto's Smart City: Everyday Life or Google Life?' Architecture_MPS, 2019, 15(1): 1, pp. 1-21. DOI:

https://doi.org/10.14324/111.444.amps.2019v15i1.001.

Published: 28 February 2019

\section{Peer Review:}

This article has been peer reviewed through the journal's standard Editorial double blind peer review.

\section{Copyright:}

(C) 2019, The Author(s). This is an Open Access article distributed under the terms of the Creative Commons Attribution License (CC-BY) $4.0 \mathrm{https}: / /$ creativecommons.org/licenses/by/4.0/, which permits re-use, distribution and reproduction in any medium, provided the original author and source are credited・DOI: https://doi.org/10.14324/111.444.amps.2019v15i1.001

\section{Open Access:}

Architecture_MPS is a peer-reviewed open access journal.

\footnotetext{
*tierney@illinois.edu

1 University of Illinois Urbana Champaign, USA
} 


\title{
Title: Toronto's Smart City: Everyday Life or Google Life?
}

\section{Author: T F Tierney}

Architecture_media_politics_society. vol. 15, no. 1 .

February 2019

Affiliation: University of Illinois Urbana Champaign, USA

\begin{abstract}
In August 2015, Google reorganized its various interests as a conglomerate called Alphabet Inc. Under the new umbrella, Google's search, data aggregation, and advertising subsidiaries, were joined by Sidewalk Lab and its suite of urban products: high-speed broadband services, Android Pixel2 phone, mobile mapping, autonomous cars, artificial intelligence, smart homes, and all the data captured therein. The City of Toronto's recent award to Alphabet's Sidewalk Lab for design services has sparked a heated controversy among urban planners and citizens alike. Toronto's decision not only signals a different model of professional practice, but it also represents a conceptual shift away from citizen to urban consumer. By engaging a private technology company, one that passively captures data on its customers and then re-sales that data to third parties, Toronto's smart city points to a significant change in the understanding and practice of contemporary urban planning and design.

Acknowledging the city as a site of disciplinary disruption, this paper introduces Bratton's stack theory as a way to understand networked urbanism more generally, and Waterfront Toronto specifically. We build on Bratton's position by closely examining twenty-first century histories and anthropologies related to the Internet, privacy, and the dominance of big data. Our principal concern is with the transformation of personal and environmental data into an economic resource. Seen through that particular lens, we argue
\end{abstract}

DOI: 10.14324/111.444.amps.2019v15i1.001, @ 2019, The Authors. This is an Open Access article distributed under the terms of the Creative Commons Attribution License, which permits unrestricted use, distribution, and reproduction in any medium, provided the original author and source are credited.

ARCHITECTURE_MEDIA_POLITICS_SOCIETY Vol. 15 No. 1 February 2019 


\section{Amps}

that Toronto's smart city has internalized relations of colonization, whereby the economic objectives of a multinational technology company take on new configurations at a local level of human (and non-human) information extraction - thereby restructuring not only public land, but also everyday life into a zone of unmitigated consumption.

DOI: 10.14324/111.444.amps.2019v15i1.001, (C) 2019, The Authors. This is an Open Access article distributed under the terms of the Creative Commons Attribution License, which permits unrestricted use, distribution, and reproduction in any medium, provided the original author and source are credited. 


\title{
Title: Toronto’s Smart City: Everyday Life or Google Life?
}

\author{
Author: T F Tierney
}

Architecture_media_politics_society. vol. 15, no. 1 .

February 2019

What would a city look like if you started from scratch in the internet eraif you built a city from the internet up?

-Dan Doctoroff, CEO, Sidewalk Labs ${ }^{1}$

The City of Toronto's recent contract with Sidewalk Labs - Google's urban technology division - has sparked a heated controversy among urban planners and citizens alike. This public-private partnership between Sidewalk and the city's development agency, Waterfront Toronto, signals a new model for urban design. Google will build on its reputation as the world's largest search and data aggregation company by layering the city with a ubiquitous wireless network on top of city services, forming an informational stack that will invisibly orchestrate communication, economics, and energy. That intelligent infrastructure will also be harvesting citizen data continuously and autonomously, twenty-four hours per day. Artificial intelligence software will analyze the resultant mass of citizen data and use it to inform decisions that will shape future city services. The citizens of Toronto have been told that the implementation of smart technologies will result in a better, healthier, safer environment. But what else is at stake? Much of the popular press's rhetoric is based on an over-simplification of the issues; yet to be discussed are the unintended consequences. To more closely examine Google's proposal, we apply a Design Theory and Methods framework as a means to critically understand the relationship between governance, economics, and personal data. ${ }^{2} \mathrm{We}$ begin the theoretical discussion by exploring the socio-economic conditions of smart cities more generally. Our analysis leads us to advance a notion that the Eastern Waterfront project represents a post-industrial colonial model, one that extracts personal and environmental data as an economic resource, redefining the citizenry as a commodity. 


\section{Amps}

\section{Stack Theory}

What would a city designed from the Internet up look like? First, several technical limitations need to be solved. As urban planner Anthony Townsend, among others, has noted, wireless infrastructure is neither robust nor secure. If the city becomes totally connected, hacking attacks become a substantial concern. ${ }^{3}$ However, for the sake of argument, let us assume that those problems have been eliminated and that a fully secure wireless robust network has been developed. Then much larger concerns related to society demand our attention.

Whether for reasons of increased efficiency or sustainability, there has been a move toward greater command and control in everyday life. During the 1980s IBM and Microsoft effectively colonized the work environment by introducing a suite of computational programs and methods to corporations, and this development was soon followed by the fully networked office. The very nature of computational exchanges allows for the monitoring of each and every action: regulating employees' time, spying on their correspondences, doing cost-benefit analysis along with more traditional accounting.

Having successfully conquered the office territory, technology conglomerates, including Google among many others, began searching for new markets to colonize. Although cities have been competing for the campuses of mega corporations by offering tax breaks (recently to Amazon, for example), Alphabet advanced those ideas further by actively seeking urban environments in which to implement its ideas. ${ }^{4}$ While urban planners have proposed test-bed situations to obtain more accurate feedback, it was always with the intention of working with existing institutions or entities, for example universities, or in the European Union, innovation areas, and/or research-driven cities such as Issy in France or Zaragoza in Spain. ${ }^{5}$ Building a new city from the Internet up is a different proposition. How are we to better understand what is being proposed?

Benjamin Bratton offers a theoretical perspective called The Stack. ${ }^{6}$ For Bratton, The Stack describes the global information economy, in other words, the digital market economy. It is not only a way to map political geography but also a way to name the forces defining that territory. The Stack is both a theoretical machine and a thing, what Bratton describes as a "schema of machines." An example is an algorithm, which is both an abstract machine and an agency of action because it does things in the world. Geographers Rob Kitchin and Martin Dodge characterize this aspect as "code/space," defined as "when software and the spatiality of everyday life become mutually constituted, that is, produced through one another."7 Code/space is increasingly pervasive in everyday life - ranging from airport check-in kiosks to self-service check-out lanes at grocery stores to mobile apps such as Uber's. What distinguishes The Stack from code/space is that the former is conceptualized as a ubiquitous layering of invisible (or backgrounded) technologies with physical space through Wi-Fi and the Internet of Things.

We consider The Stack a way to understand networked urbanism more generally, and Sidewalk Toronto specifically, and the way technology conscribes, 
shapes, and disciplines its users within the urban environment. As a conceptual framework, what we are delineating is an all-encompassing global computation system, one that includes energy generation, distribution grids, off site server farms (the cloud), and information and communication networks, in addition to users, described by Bratton as "both over-outlined by selfquantification, and also expanded by the introduction of environmental sensors, algorithms, and robots." The system as a whole, he says, should be viewed not "as a hodgepodge of different species of computing, spinning out on their own at different scales and tempos, [rather] we should see them as forming $a$ coherent and interdependent whole [italics added]."8 Those technologies align layer by layer, into something like a vast, if also incomplete, pervasive, if irregular software and hardware stack.

This multilayer networked stack includes all the infrastructural elements of the city - its utilities, streets, public transportation, information and communication systems, and so on. And yet, this stack is neither static nor an inert structure: it is a highly reflexive system, operating as a feedback loop. A quotidian example is a thermostat, since it collects data (temperature) through a sensor. When the temperature goes beyond a prescribed range, the thermostat automatically triggers a reaction modulating the environment. In a similar manner, an informational stack collects urban data (including data from residents) and then automatically recalibrates to accommodate infrastructural demands, tuning the city in real time.

While The Stack is an accidental megastructure that we are building both deliberately and unwittingly, it is in turn building new social organizations in its image. ${ }^{9}$ Previously, Foucault argued that governance is expressed and configured through the specific technologies and techniques with which it produces its own subjects and objects. ${ }^{10}$ In the same way, The Stack is an effect as much as a cause of how certain machines and mechanics organize urban bodies over time. Those configurations may be enforced through legislation, but governance is just as much invented by those processes as are the laws it promulgates. If, according to Foucault, the city is a social construction of everyday life, then how does The Stack manifest? The Stack's primary means and interests are ciphering the world's information: hence, it sees the world as information. Bratton cautions that "we the humans, while included in this mix, are not necessarily its essential agents and our well-being is not its primary goal." 11 Thus, the algorithm effectively acts as the state - in that the state functions autonomously and is thus no longer subject to the will of its citizens.

\section{Background}

The Stack offers a theoretical framework with which to examine emerging smart cities. Accordingly, Google is predicting a transformation in urban infrastructure via the Internet of Things (IoT), defined as the integration of the Internet, mobile communication, and sensing technologies. Sidewalk Labs' CEO Daniel Doctoroff argues that the greatest periods of economic growth 
and productivity have occurred when innovation was integrated into the city fabric. His examples include the steam engine, electric grid, and street car inventions that substantially advanced the economic and social infrastructure of cities. ${ }^{12}$ Now, Google is betting on the Internet to make a similar impact.

Before further analyzing Google's proposal for Toronto, we want to emphasize that Google is more than a simple search engine. While the company provides search engine and email services gratis, those services are offered in exchange for collecting information on users. Google then sells that information to advertisers to better position and market their products. Or, as Google's annual report succinctly puts it, "We generate revenue primarily by delivering relevant, cost-effective online advertising." 13 According to Google, about 70 percent of its advertising revenues come from AdWords: contextual advertisements targeted based on the user's location and search term. Another 28 percent of revenues are derived from AdSense, which targets previous user behavior. Google's AdSense network places advertisements on partner sites from blogs to major content publishers such as the New York Times - with Google taking a significant share of the revenue. While 96 percent of Google's revenue comes from advertising, the company also invests $\$ 1.5$ billion in what it terms "enterprise products" (in other words, aggressively buying up other start-ups and non-advertising companies). Currently, Google (or rather its parent company) is one of the world's largest revenue-generating corporations - with an economic model that has made billions collecting and selling information from its users.

In 2015, prior to the Toronto Eastern Waterfront project, Google's international holding company went through a rebranding and reorganization effort, changing its name to Alphabet Inc. ${ }^{14}$ Under the new umbrella, Google's search, data aggregation, and advertising subsidiaries were joined by Sidewalk Labs and its suite of urban products: high-speed broadband services, the Android Pixel 2 phone, mobile mapping, autonomous cars, artificial intelligence, smart homes - and all of the data captured by those devices.

During the repackaging phase, Doctoroff turned his gaze toward "clean slate scenarios" - which is to say physical sites that are unencumbered by complex histories and regulations - to be used as test grounds for Sidewalk's products, where it could begin vigorously promoting its services. ${ }^{15}$ In New York City, public Internet kiosks known as LinkNYC were installed to serve as repeaters of a larger mesh networked system connecting diverse transit systems. ${ }^{16}$ Since transportation is one of the first targets for disruption (Alphabet invested in Uber, Waymo, and Lyft), during that period Sidewalk Labs also began testing its cloud-mobility software, FLOW, in partnership with several other municipalities. ${ }^{17}$ In 2016, Sidewalk Labs also solicited the US Department of Transportation for federal funding related to a \$50 million Smart City Challenge which was subsequently awarded.

As a result, Sidewalk Labs was better prepared than most planning practices when Waterfront Toronto sent out a "request for proposals" (RFP) to develop a former industrial zone into a new city for ten thousand residents. 


\section{Amps}

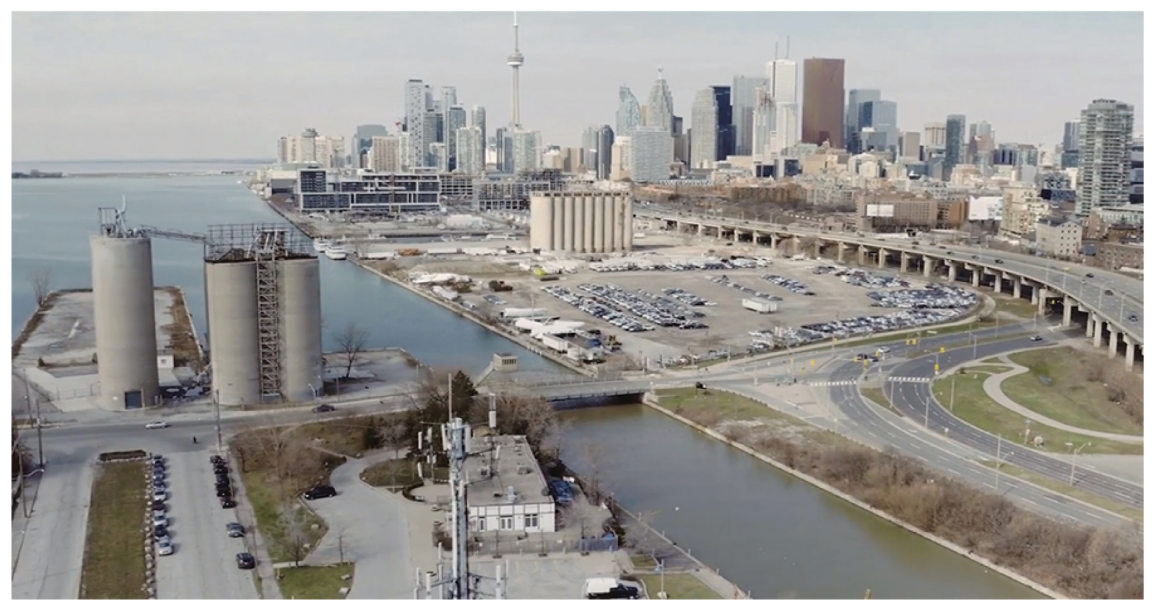

Figure 1: Toronto Eastern Waterfront aerial view 2018. Source: Sidewalk Labs.

The 13-acre site adjacent to Lake Ontario represents approximately three million square feet of development. By June 2017, Waterfront Toronto had winnowed the RFP responses to a short list, although that list was never made public. ${ }^{18}$ Then, in September, the city agency announced that the commission had been awarded to Sidewalk Labs. Typically, a city awards a contract to a planning firm for services to be rendered, but in Toronto the relationship was reversed. According to the terms of the agreement, Google will pay the city of Toronto $\$ 50$ million dollars for the opportunity to develop the site. If the development goes ahead as planned, "Sidewalk Toronto" will be one of North America's largest examples of a smart city project - that is, a place built around data-driven, automated, networked technologies.

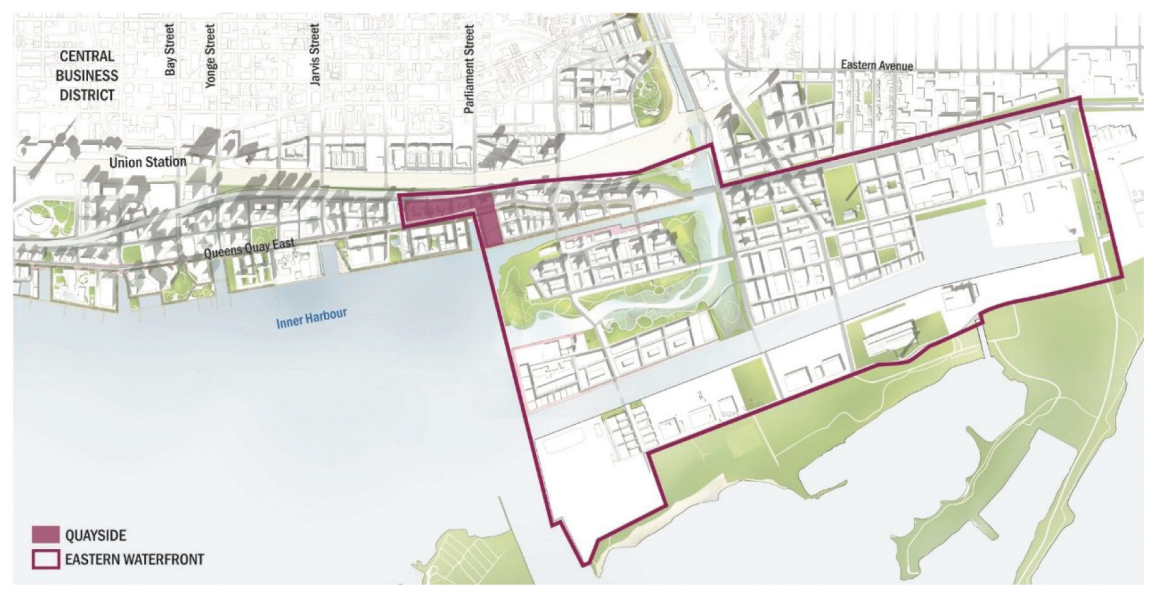

Figure 2: Map of Toronto Eastern Waterfront development area. Source: Sidewalk Labs. 


\section{Amps}

At the public announcement, Canadian Prime Minister Justin Trudeau led the way in heralding a new urban age. He promised that the Eastern Waterfront development would create "technologies that will help us build smarter, greener, more inclusive communities. It offers unprecedented opportunities and will create thousands of middle-class jobs. I have no doubt that it will become a model for cities around the world and make all of our communities better places to live." ${ }^{19}$ Sidewalk Lab's 156-page proposal describes a city of the future - with elevated pedestrian walkways, delivery drones, and autonomous cars. Within this district, Sidewalk Labs will have its own "urban living laboratory," where it can experiment with new smart systems. Different types of electronic data collection - using mobile phones, laptops, cameras, cars, and sensors - will collectively supply information that will be used to manage assets and resources more efficiently. The data will be processed and analyzed to monitor and manage traffic and transportation systems, power plants, water supply networks, waste management, law enforcement, information systems, schools, libraries, hospitals, and other community services. Sidewalk Labs claims that its involvement will result in the optimization of resources and a reduction in energy use.

Overall, Google's vision promises an effective, efficient city for its residents through the integration of information and communication technologies (ICTs), and of the various physical devices connected to the network - the Internet of Things. Ideally, networked technologies will allow city officials to interact directly with both community and city infrastructure and to monitor what is happening in the city and how the city is evolving in real time. ICTs can be used to enhance the quality, performance, and interactivity of urban services; to reduce costs and resource consumption; and to increase communication between citizens and government. And in a strategic move, Alphabet/ Google's new Canadian headquarters will be located on the site, along with new Alphabet employee housing and new employee services, including an autonomous transit infrastructure, all of which will facilitate this vision. ${ }^{20}$

\section{Smart Cities' Special Economic Zones}

Toronto's Eastern Waterfront project invites comparison with other urban prototypes. Not only is the planned community different from industrial towns of the past, it is also different from contemporary smart cities, more accurately termed, special economic zones (SEZs). ${ }^{21}$ The primary difference between the two lies in their intentionality: SEZs are designed to stimulate international investment and increased participation in the global market economy, whereas the Sidewalk Toronto is intended as an experimental urban laboratory.

Before further teasing out the differences between smart cities and SEZs, let's consider a hybrid example: the nation of Estonia combines both SEZ and urban laboratory. In Estonia's case, smart-city initiatives were designed to support the Estonian Regional Development Strategy goals of environmental sustainability and increased international economic competitiveness. 
The country's innovative policies include smart governance (e-governance and e-services) designed to expand public participation. Estonia is internationally known for its elevated social trust towards e-government solutions, in which privacy-related issues have very little impact on policy debates, and ICT has become one of the building blocks of national branding and citizen participation. ${ }^{22}$ In many ways, Estonia is leading the way in participatory practices that other smart cities could emulate.

Unlike Estonia's participatory democracy, a typical SEZ is a designated territorial zone within which tax exemptions and freedom from other governmental restrictions apply, including expedited customs and administrative procedures. For example, in India, SEZs fully exempt foreign corporations from income tax for the first five years and reduce taxes by 50 percent for five years thereafter. In Korea, a SEZ exempts foreign corporations from taxes for three years and reduces them by 50 percent for two more years. Labor is also typically deregulated in a SEZ - in other words, foreign firms are exempt from policies designed to ensure equitable hiring practices. In that respect, SEZs are simultaneously autonomous and exclusive. Foreign investors are absolved from normative regulations and can establish their own schools and hospitals with exclusive admission policies. ${ }^{23}$ International employees reside in SEZs temporarily and they have no rights, nor voice in the community. Border conditions exist at perimeters with identity cards required to gain admittance. In that sense, a SEZ is not a polis, but purely a specially designated economic zone. The "smartness" label merely serves as an attractive branding device that reassures investors that the SEZ is enhanced with the advanced information and communication infrastructure needed to facilitate modern global business practices.

An ongoing critical discussion on the territorial implications of free-trade zones has been in progress for many years. It generally focuses on aspects related to political decentralization and economic liberalization policies. Urban theorists Keller Easterling and Saskia Sassan describe SEZs as exemplifying local disconnection overlaid by global connection. ${ }^{24}$ Social scientists Stephen Graham and Simon Marvin advance a similar claim by arguing that networked infrastructure is unevenly distributed; they draw attention to the socially embedded nature of ICTs, which mediate both connections and disconnections among different social agents. Though nations may attempt to increase their competitiveness through special zoning policies that legitimate selective investment, those same policies lead to uneven "splinters" in the local region. ${ }^{25}$ Given such uneven economic regulation, theorist Chamee Yang suggests, SEZs prioritize "insiders over outsiders; capital, information, technology over the have-nots; young entrepreneurs and professionals over the elderly, less skilled and uneducated." ${ }^{26}$ And in the eventual case of an experimental urban laboratory, such as Sidewalk Toronto, where Google employees will reside and work, that privileging of profitability and exclusivity will skew future experimental results, possibly suggesting efficiencies that cannot be duplicated in an actual city with a population of diverse ages, incomes, and health. 


\section{Amps}

What is a greater matter of concern, however, are the similarities in measures of surveillance and control. Both SEZs and Sidewalk Toronto are laden with CCTV cameras that follow residents and workers. These surveillance devices are employed for different reasons in the two models: In a SEZ, safety and security for international business affairs is a top priority, as the anxieties of multinational corporations need to be assuaged prior to investment and relocation. In Asian smart cities, such as South Korea's Songdo and China's Shenzen, a heightened level of surveillance was made possible because of a historically lower expectation of personal privacy than in the West. ${ }^{27}$ While SEZs are blanketed with CCTV cameras, those surveillance measures predate the IoT and the ubiquitous harvesting of information, so the potential misuse of shared data is not (yet) an issue in these areas.

In contrast, Sidewalk Toronto will have not only CCTV cameras, but also a plethora of environmental sensors. Those sensors, whether they are mounted on street lights or embedded in sidewalks, will capture wireless communications from mobile phones, tracking everyone who lives, works, or merely passes through the area. And while such surveillance promises safety, it is also unremittingly invasive. Sidewalk's stated intention is to collect and analyze citizen data to better predict and plan for the efficient deployment of resources, as well as to augment the fulfillment of consumptive desires. But who is in charge of securing the data? And for how long? Those questions have not yet been answered. We will return to those important concerns later.

In addition, Sidewalk Labs promises new rules for its urban test bed: more "bottom up" decisions and fewer layers of hierarchies making them. If Sidewalk follows Estonia's lead, this could contribute to increased citizen involvement and participation. In exchange, however, Sidewalk Labs is demanding the suspension of existing planning and transportation regulations that govern other areas of the city - planning regulations that were created for the protection of the health and safety of residents. Suspending them has never been tried before, and the consequences are unknown. In this way, the partnership not only threatens existing planning practices (what architecture and planning firm can compete with a rival that offers $\$ 50$ million to a client?), but the world's largest searching-mapping-driving-advertising-company is throwing its resources behind an urban Internet of Things, permanently embedding its search, geolocation, sensors, and delivery broadband into the urban fabric. ${ }^{28}$

\section{Postindustrial Colonialism}

\section{Facebook's sales motto is "Build big communities and you will own them." - Scott Galloway ${ }^{29}$}

Our principal concern with Toronto's Eastern Waterfront is the role of personal and environmental data as an economic resource. One definition of consumption is the process by which "the substance of a thing [in this case, data] ... 
is incorporated or transformed into something else [a commodity]." ${ }^{30}$ Google has built an online empire by quantifying everything: clicks, page views, visits, GPS coordinates, motor vehicle traffic. The company's resource is information about people, which it mines, packages, repackages, repackages again, and then reuses to sell you stuff. ${ }^{31}$ Let's take another example, Facebook creates an online community where its members create content about their everyday lives. At the same time, Facebook owns that community. ${ }^{32}$ It then collects data on its community members, aggregates their data, and sells that personal data to advertisers. In a similar way, Sidewalk Labs intends to develop the Toronto site to house a physical community, collect data reflecting behavior and consumption patterns, analyze the data, and sell that information to advertisers. But in a strategic move, Alphabet can also sell its own suite of urban products (high-speed broadband, Android mobile phone, apps, and advertising) back to the community. ${ }^{33}$ Is this what twenty-first century colonialism looks like? Or is the arrangement quid pro quo? Alphabet says it is giving resources back to Toronto, but at the same time it may extract billions of dollars from the community over time, using tools ordinary citizens have no access to.

In the past, a colonial economy referred to a system of production and consumption, introduced to fulfill the state's economic demands for new resources, markets, and investments. Similar to how European nations aggressively expanded the colonial project during the late eighteenth century, so too Sidewalk Toronto internalizes relations of colonization whereby the economic objectives of a multinational technology company take on new configurations at a local level of human (and non-human) information extraction, thereby transforming not only public land but also everyday life into a zone of unalloyed consumption (consumption here being defined as the extraction, processing, and resale of information). ${ }^{34}$ Thus Sidewalk Labs is in the process of effectively colonizing the postindustrial city.

\section{Google Sidewalk Labs includes}
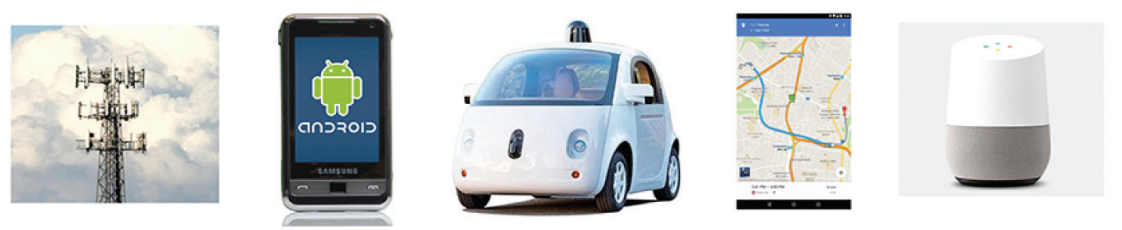

Figure 3: Suite of Alphabet's urban products. Source: URL: Urban Research Lab. 
Now Alphabet attempts to negate its economic aspirations by calling its design operations - a "platform." ${ }^{35}$ Let's consider the definition of Uber as an "urban platform." The European Union courts determined that Uber is not a platform. Rather, it is a "closed transit company," wherein the corporation controls everything; thus, the courts ruled it should be regulated. ${ }^{36}$ However, no similar regulation exists in the United States or Canada as yet. ${ }^{37}$

The Stack is evidence of other shifts of formerly public services into private, for-profit hands. Contemporary cities are under economic pressure, and while Sidewalk Labs promises efficiency, sustainability, and well-being-who ultimately benefits? Reviving Lefebvre's critique supports the argument that the market economy is characterized by contradictory tendencies that (1) increase standardization in everyday life (a regularity in work and objects through a general commodification) at the same time that (2) social inequalities increase (the intensification of class, race, gender, or age hierarchies). ${ }^{38}$ Responding to the first concern, optimization algorithms magnify standardization. For example, we all know that public transit does not make a profit. However, the objective for a city is universal accessibility, not profitability. ${ }^{39}$ What happens when transit is "optimized"? Typically, the transit lines in less profitable neighborhoods are reduced or dropped. This brings us to Lefebvre's second point, that social inequities are intensified.

\section{Sensor Fusion}

The wholesale embedding of environmental sensors, allowing for twentyfour-hour surveillance of citizens, thus far has not received enough discussion. ${ }^{40}$ While the Internet has been in everyday use for decades, what is new about intelligent infrastructural systems is self-awareness. Smartphones, the most ubiquitous intelligent device, incorporates sensors such as an accelerometer, compass, and GPS; however, the high cost of those sensors formerly prevented them from being used indiscriminately in the environment. That has changed. The recent affordability of sensors allows their widespread use in means of transportation and devices of all kinds - stationary, mobile, even wearable (the Apple Watch). Increasingly, inexpensive wireless sensors will be embedded in the urban environment, creating sophisticated large-scale sensor networks. Within these networks, smartphones will effectively act as wireless hubs for other devices, connecting the Internet of Things (IoT) at the urban scale. $^{41}$

One problem is that sensor data is particularly difficult to anonymize. ${ }^{42}$ Another problem is that the Internet of Things reveals unexpected inferences through the cross referencing of data, known as sensor fusion. ${ }^{43}$ By using GPS coordinates to pinpoint and filter out particular individuals by address, discriminatory practices may be inserted into decision-making algorithms. Geoblocking, a related practice, is used to restrict access to premium multimedia content on the internet, such as films and television shows, primarily for copyright or licensing reasons; however, there are other uses for geoblocking, 
such as to enforce price discrimination or location-aware authentication. Visà-vis geographic indexing, certain neighborhoods, ethnicities, and/or sexual orientations that represent a higher health or safety risk, also can be filtered out and rejected. Or within a black-box algorithmic environment, according to historian Yuval Harari, a person can be discriminated against simply for being "different" and never know the reasons for rejection. ${ }^{44}$

Lastly, the possibility of algorithmic "profiling" by domestic police forces is a serious danger. Studies have shown that law enforcement has structured biases in its data-driven models. According to informatics researcher Shannon Mattern:

Contemporary models of "actuarial justice" and "predictive policing" draw correlations between specific risk factors and the probability of future criminal action. Courts and police make decisions based on proprietary technologies with severe vulnerabilities: incomplete datasets, high error rates, demographic bias, opaque algorithms, and discrepancies in administration ... Palantir software now used by some local governments merges data from disparate city agencies and external organizations, enabling police to collate information about suspects, targets, and locations ... Key analyses, even decisions about where to deploy resources, are automated, which means that no human need ever look at the actual raw data. ${ }^{45}$

The practice of algorithmic profiling makes each connected device important as a policy matter, because data can be used to make decisions about policing, insurance, employment, credit, housing - with the possibility of creating new forms of racial, gender, or other discrimination against protected classes.

Residents and workers in Sidewalk Toronto will rely on Sidewalk-developed software to gain access to public services, and the data gathered from everyone and everything will influence long-term planning and development. While Sidewalk Labs says users will be able to decide what they want (which could be fraught with its own concerns), the larger question is what choices are being offered. Feedback is confined to a narrow list of products. There is no check box for "no monitoring" or "opt out." According to the New York Times, "extending the surveillance powers of one of the world's largest technology companies from the virtual world to the real one raises privacy concerns for many residents ... [Planners] caution that, when it comes to cities, data-driven decision-making can be misguided and undemocratic." 46 With data analysis, there is no consideration of context, no opportunity for expression or deliberation or debate. Data decides. In Sidewalk Labs' scheme, residents provide (unpaid) feedback about the products they use - but without gaining any political agency in return.

\section{Policy and Regulation}

At Waterfront Toronto's citizens' meeting on November 10, 2017, residents expressed two main concerns: (1) that the reliance on data for decision-making 
was too heavy and (2) that those data decisions were perceived to be infallible. Those concerns are not insignificant: they need to be heeded. ${ }^{47}$ The increasing power of data to make decisions in determining how we live our lives how we engage, who talks to whom, and who is allowed to play - is moving from the Internet to the physical world, which has serious consequences for urban governance. Waterfront Toronto's partnership with Sidewalk Labs not only signals a different model of planning practice, but also a conceptual shift away from citizen toward commodifiable data generator. Currently, technology companies harvest data with little regulation and without disclosure as to what purpose the data will serve. It is Alphabet's stated goal to track who you are and what you do, including location and off-platform activities. The assembling of this information and use of it to predict and manipulate future choices may mean that we become unable to distinguish the menu of restricted options from our own ideas. ${ }^{48}$

In that context, the expression "If you're not paying for it ... you're the product being sold" means that users are Google's "product." 49 Not only do user/citizens generate free data and content, but Google also sells those users to advertisers, although Google might argue that it is more accurate to say information about users is its product. While consumers benefit from convenience, what is at stake here? What appears to be an emphasis on lifestyle customization at the user end is actually veiling the commercial practice of personal data mining on the provider end. Users perceive a gain in control, whereas they are in fact being constantly monitored. ${ }^{50}$ The implications for urban dwellers could hardly be more serious as Sidewalk Lab's invisible networked infrastructure is being buried beneath the road surface, along with many of our historical definitions and rights of citizenry.

The tendency to regard technology as value-neutral is merely a way to evade the inherent political controversies and consequences. ${ }^{51}$ In the United States as yet, neither the Federal Communication Commission (FCC) nor the Federal Trade Commission (FTC) has imposed any regulation or protections. While the FTC ruled that Facebook has engaged in "unfair and deceptive" practices with regard to changes made to its privacy settings in 2009, those rulings were later rescinded. ${ }^{52} \mathrm{~A}$ non-regulatory environment clearly contributed to the political uses to which Facebook data has been put more recently. ${ }^{53}$ Legal experts say there must be restrictions on the collection, compilation, and analysis of data about people - whether it is anonymous or not. It must be emphasized that while we are not advocating for overregulating the city, nonetheless, the Internet, similar to water, energy, or telecommunications, is a public utility, and should be regulated as such.

One measure to keep platforms such as Google in check is to prevent them from appropriating all the adjacent peripherals - which corresponds with Sidewalk's suite of urban products. ${ }^{54}$ Additionally, making sure that individuals can move their identities between platforms - as well as browsing histories and maps of social connections - is required. Most importantly, it is critical to treat other technical components of the emerging platform landscape - from 
services that can verify our identity to new payment systems to geolocational sensors - as actual infrastructure and/or utilities. This step is essential to ensure that everyone can access these services on the same, nondiscriminatory terms.

\section{Conclusion}

The rhetoric of "smartness" confers an ideology of efficiency, optimization, and safety. Sidewalk Labs perpetuates those myths, including the infallibility of big data to make accurate decisions. ${ }^{55}$ While urban planners rely on data to better understand the city and its residents, their education in the social sciences prepares them to conceptualize data as only one part of the planning process. It is through exposure to the social sciences that interpretive critique is mastered; planners are trained to reduce bias through their methodologies, including the forming of hypothesis, qualitative methods, and peer review. Thus, there is warranted concern about smart cities among professionals and laypersons alike related to the use and operations of data. Data privacy is important, but no less so are our historical rights to have a stake in shaping the future of our communities. In this situation, the more important question is not what an Internet city would look like, but what a user-generated city would look like.

As modes of governance fail to keep up with a changing society, the concept of cities and citizenship is changing as well. Nonetheless, Lefebvre's call that the "right to the city is a renewed right to urban life" is as relevant now as in the 1960s. ${ }^{56}$ In response to technologically driven designs, Lefebvre might argue that the complexity of a city cannot be reduced to a spreadsheet. For many, the seeming chaos of cities holds the freedom for people to improvise and find opportunities and surprises that would disappear in an optimized environment where decisions are driven by data. To programmers, systems that run smoothly, efficiently, and bug-free is the goal. Cities, in contrast, attain much of their character through dysfunction; their randomness inspires improvisation - what Reijndorp called "controlled un-control." ${ }^{57}$ For example, Berlin's public transportation system advertises its flaws because people like its "personality." ${ }^{58}$ Similarly, many old-time New Yorkers bemoan a loss of the city's character caused by reforms in the 1990s.

Given today's slippery redefinition of citizenry and urban sovereignty, what has governance done to address these challenges by tech giants? In a similar project, in Columbus, Ohio, the technology conglomerates failed to fulfill their promised objectives. ${ }^{59}$ With regards to privacy, the Republic of France has sued Google for privacy breaches, as have Germany and many other countries. ${ }^{60}$ If the European Union courts determined that Google broadband and self-driving transit act not as "platforms" but instead as utilities, then it follows that these utilities require citizen oversight and regulation. For Toronto, what can their citizens rely on: human rights or end-user agreements? Are they obligated to accept every service embedded in every software-enabled object or surface? ${ }^{61}$ We ask, what referent of last resort can be relied upon? 


\section{Amps}

While data can assist planners in understanding cities better, it seems clear that the bigger issue is that a city is not fundamentally a technological problem. A city has to create ways for large numbers of people to live together in a relatively small space. People need to live safely and peacefully; they need to be able to rely on public transit, to obtain nourishment and potable water, to have education, and employment opportunities. Achieving those requirements (which Toronto has done better than most North American cities) is a problem of politics, economics, and sociology in the sense of relations between groups. A city uses technologies to achieve these things, but technologies are not the fundamental driving force. Whatever happens in the future - however we as citizens decide to apply smart technologies - we must ensure that any ongoing developments lead to cities that are more humane, not less.

Note: Portions of this paper were presented at the annual conference of AMPS (Architecture Media Politics Society), University of Arizona, February 11, 2018, and at the Associated Collegiate Schools of Architecture Conference/ COAM, Madrid, Spain, June 14, 2018.

\section{Notes}

1 Daniel L. Doctoroff, "Reimagining Cities from the Internet Up," Medium, November 30, 2016, accessed January 30, 2019, https://medium.com/sidewalktalk/reimagining-cities-from-the-internet-up-5923d6be63ba.

2 Christopher Alexander, Horst Rittel, Chris Jones, and Bruce Archer were four key members who founded the Design Theory and Methods Movement that argued for the application of a rational approach to design and research. At University of California Berkeley, Rittel went on to propose a "second generation" of design methodology, which placed a larger value on user participation. The present-day "third generation" focuses on computational design methodologies. From Christopher Reznich, "1973: Horst Rittel \& Design Methodology," Medium, February 19, 2017, accessed January 30, 2019, https://medium.com/ designscience/1973-7921763949fd.

3 Anthony Townsend, Smart Cities: Big Data Civic Hacking and the Quest for a New Utopia (New York: W. W. Norton, 2013), 252-81. Also see Rob Kitchin and Martin Dodge, "The (In)Security of Smart Cities: Vulnerabilities, Risks, Mitigation, and Prevention," Journal of Urban Technology, December 12, 2017, accessed January 30, 2019, https://www.tandfonline.com/doi/full/10.1080/106307 32.2017.1408002.

4 See Julie Creswell, “Cities' Offers for Amazon Base Are Secrets Even to Many City Leaders," New York Times, August 5, 2018, https://www.nytimes.com/2018/08/05/ technology/amazon-headquarters-hq2.html.

5 The author was a US delegate for the Consulate General of France to the Smart and Digital Cities Tour in 2013. See "Smart and Digital Cities Tour: A Delegation of American Experts Invited to Attend the Paris Digital World Festival Futur-enSeine in June," PR Newswire, June 10, 2013, accessed January 30, 2019, https:// 
www.prnewswire.com/news-releases/smart-and-digital-cities-tour-a-delegationof-american-experts-invited-to-attend-the-paris-digital-world-festival-futur-enseine-in-june-210884131.html.

6 This model, informed by the logic of the multilayered or "stacked" protocol structure, in which network technologies operate within a modular, vertical order, offers a comprehensive image of our emerging smart cities.

7 Rob Kitchen and Martin Dodge, CodelSpace: Software and Everyday Life (Cambridge, MA: MIT Press, 2011), 16.

8 Benjamin Bratton, The Stack (Cambridge, MA: MIT Press, 2015), 5.

9 Stephen Graham and Simon Marvin, Splintering Urbanism: Networked Infrastructures, Technological Mobilities and the Urban Condition (London: Routledge, 2001), 8.

10 Michel Foucault, "Two Lectures," in Power/Knowledge: Selected Interviews and Other Writings from 1972-1977, ed. Colin Gordon (New York: Pantheon Books, 1972).

11 Ibid, 8.

12 Shannon Mattern, “The City Is Not a Computer," Places, February 2017, accessed January 30, 2019, https://placesjournal.org/article/a-city-is-not-a-computer.

13 Greg McFarlane, "How Does Google Make Its Money?" Investopedia, November 12, 2012, accessed January 30, 2019, https://www.investopedia.com/stock-analysis/2012/what-does-google-actually-make-money-from-goog1121.aspx.

14 Most of Alphabet's staff are employed at Google's corporate headquarters, as are Android's, YouTube's, Google Apps', Google Maps', and Google Ads'. Another seven companies have been established as Alphabet subsidiaries: Calico, Google Life Sciences, Nest Labs, Google Fiber, X, Google Ventures, and Google Capital. Alphabet's vertical integration of products is conceptualized as urban building blocks - a software/hardware grammar that assembles a smart city.

15 Alphabet's real estate division looked at approximately 150 different cities to find an ideal experimental site.

16 While New York promoted the kiosks as free public Internet access, the search engines were disabled when low-income residents began to use the kiosks. See Patrick McGeehan, "Free Wi-Fi Kiosks Were to Aid New Yorkers. An Unsavory Side Has Spurred a Retreat," New York Times, September 14, 2016, https://www. nytimes.com/2016/09/15/nyregion/internet-browsers-to-be-disabled-on-newyorks-free-wi-fi-kiosks.html.

17 In 2016, the Department of Transportation (DOT) solicited research proposals for the $\$ 50$ million Smart City Challenge. Alphabet, AT\&T, and other corporations obtained provisions from DOT to partner with the winner. Columbus's winning proposal had a strong social focus, promising to use transportation to improve the city's underserved neighborhoods. Autonomous vehicles would be used to link the Linden neighborhood, where unemployment was three times the overall city average, to a nearby jobs center. City officials said that the new service would also help poor families get better access to health care and other essential services. They promised that the $\$ 50$ million grant would serve the low-income population by creating transit cards for ride-hailing services, even 
if those residents didn't have a smartphone or a bank account. As of January 2018, Columbus has not implemented any of those services for South Linden residents. See Daniel C. Vock, "Why Columbus Won the Smart City Challenge," Governing, June 23, 2016, accessed January 30, 2019, http://www.governing.com/ topics/transportation-infrastructure/gov-columbus-ohio-smart-city-winner.html.

18 According to Carol Webb of Waterfront Toronto: "The Request for Proposals, and the responses, included confidentiality provisions and only the name of the successful proponent was announced. The names of the other proponents were not made public.” Carol Webb, email correspondence with author, January 8, 2018.

19 Colette Murphy, "Toronto Must Share the Sidewalk Equitably," Canada 24 News, October 22, 2017, http://www.canada24news.com/opinion/toronto-must-sharethe-sidewalk-equitably/33130-news.

20 The Eastern Waterfront development will be primarily populated by Alphabet employees, who are relatively affluent, able, and healthy, thus skewing research experiment results. While Sidewalk Labs' promotional film illustrates an inclusive city, its 156-page design proposal does not mention Toronto's underrepresented populations - the unemployed, single parents, and the homeless - and no provisions are included for them.

21 The category SEZ covers a broad range of more specific zone types, including free trade zones, export processing zones, industrial estates, and others. Most commonly the objective of an economic zone is to increase direct international investment by foreign investors, typically a multinational corporation.

22 Priscilla Ferranato and T. F. Tierney, "Civic Data and Citizenship in Midwest Urban Contexts" (unpublished paper).

23 Chamee Yang, "The Paradox of Urban Mobility and the Spatialization of Technological Utopia," in Intelligent Infrastructure: Zipcars, Invisible Networks \& Urban Transformation, ed. T. F. Tierney (Charlottesville: University of Virginia Press, 2017), 186-208.

24 Keller Easterling, Extrastatecraft: The Power of Infrastructure Space (London: Verso, 2014); Saskia Sassen, The Global City: New York, London, Tokyo (Princeton, NJ: Princeton University Press, 2001); Saskia Sassen, Territory, Authority, Rights: From Medieval to Global Assemblages (Princeton, NJ: Princeton University Press, 2008).

25 Stephen Graham and Simon Marvin. Splintering Urbanism.

26 Yang, The Paradox of Urban Mobility, 196.

27 Pamela Licalizi O'Connell, "Korea's High-Tech Utopia," New York Times, October 5, 2005, https://www.nytimes.com/2005/10/05/technology/techspecial/ koreas-hightech-utopia-where-everything-is-observed.html.

28 Mark Weiser, "The Computer for the 21st Century," Scientific American 265, no. 3 (September 1991): 94-104. doi:10.1038/scientificamerican0991-94.

29 Scott Galloway, The Four: The Hidden DNA of Amazon, Apple, Facebook and Google (New York: Penguin, 2017), 165.

30 "Consumption," Business Dictionary, http://www.businessdictionary.com/ definition/consumption.html.

31 Adam Greenfield, Radical Technologies (London: Verso, 2017), 24. 
32 Galloway, The Four, 165.

33 We do not mean to imply that Sidewalk Toronto residents will not have other choices. While all residents will access Alphabet's broadband network, restricting the type of phone or apps would not be possible, although Alphabet employees most likely, through peer pressure or otherwise, will be encouraged to use Android products.

34 According to Yuval Harari, as organizations become increasingly skilled at deploying artificial intelligence, big data, and algorithms to do everything from improving transportation systems to predicting genetic diseases, our future value may be determined only by the data we generate. See Yuval Nova Harari, "Dataism Is Our New God," New Perspectives Quarterly 34, no. 2 (2017): 36-43, accessed January 30, 2019, https://onlinelibrary.wiley.com/doi/10.1111/npqu.12080.

35 According to one tech dictionary, the meaning of platform is an operating system; however, marketing jargon has rendered the term almost meaningless. See "Platform," TechTerms, accessed January 30, 2019, 2019, https://techterms.com/ definition/platform.

36 Owen Bowcott, "Uber to Face Stricter EU Regulation After ECJ Rules It Is a Transport Firm," The Guardian, December 20, 2017, https://www.theguardian. com/technology/2017/dec/20/uber-european-court-of-justice-ruling-barcelonataxi-drivers-ecj-eu.

37 New York did just decide to limit the number of Ubers and Lyfts, however. See Aarian Marshall, "New York City Goes After Uber and Lyft," Wired, August 8, 2018, accessed January 30, 2019, https://www.wired.com/story/new-york-citycap-uber-lyft.

38 Henri Lefebvre, Critique of Everyday Life, Volume 1: Introduction (London: Verso, 1991), 49.

39 Mark S. Foster, "The Automobile in the Urban Environment: Planning for an Energy-Short Future," The Public Historian 3, no. 4 (Autumn, 1981): 23-31, accessed January 30, 2019, https://www.jstor.org/stable/3376842.

40 A data commissioner in Hamburg, Germany, insisted on inspecting the hard drive of one of Google's mapping cars to make sure that they were taking photos only of streets and buildings. The data commissioner subsequently discovered that Google was also downloading data from open Wi-Fi networks, which is to say, personal information, as its survey cars went down the streets. Google denied it was doing this. See "Why Your Cellphone Could be Called a 'Tracker'," Fresh Air, September 6, 2012, accessed January 30, 2019, https://www.npr. org/2012/09/06/160627856/why-your-cell-phone-could-be-called-a-tracker.

41 Ibid.

42 Sensor data is particularly difficult to anonymize, and sensors may be used for many purposes beyond their original use or context. See Scott Peppet, "Regulating the Internet of Things: First Steps Toward Managing Discrimination, Privacy, Security, and Consent," Texas Law Review, 93, no. 1 (2014), 85-176.

43 Jayavardhana Gubbi, Rajkumar Buyya, Slaven Marusic, and Marimuthu Palaniswami, "Internet of Things (IoT): A Vision, Architectural Elements, and Future Directions," Future Generation Computer Systems 29, no. 7 (2013): 1645-60. 44 Yuval Nova Harari, "Dataism Is Our New God." 
45 Shannon Mattern, "Databodies in Codespace," Places, April 2018, accessed January 30, 2019, https://placesjournal.org/article/databodies-in-codespace.

46 During its first two years in operation, Sidewalk Labs looked at 152 places in the United States and several others around the world for a site to begin building cities of the future. See Ian Austen, "City of the Future? Humans, Not Technology, Are the Challenge in Toronto," New York Times, December 29, 2017, https://www.nytimes.com/2017/12/29/world/canada/google-toronto-cityfuture.html.

47 In November 2017, the company took another step toward implementation, launching four new "labs" that will work on housing affordability, health care and social services, municipal processes, and community collaboration.

48 Felix Simon, "Google Is Building a Networked, Perfect Neighborhood in Toronto," Neue Zürcher Zeitung, December 8, 2017, https://www.nzz.ch/ feuilleton/wie-wollen-wir-leben-ld.1336803.

49 Credited to Andrew Lewis (@andlewis), "If you are not paying for it, you're not the customer; you're the product being sold," September 13, 2010, accessed January 30, 2019, https://twitter.com/andlewis/status/24380177712?lang=en.

50 Felix Stadler, "Between Democracy and Spectacle: The Front-End and the BackEnd of the Social Web," in The Social Media Reader, ed. Michael Mandiberg (New York: NYU Press, 2012), 242-56.

51 Yang, Intelligent Infrastructure, 195.

52 According to a Los Angeles Times article, the FCC protects consumers when they sign up for or use their broadband connection, and the FTC protects them when they use the products and services running over that network, for example websites, social networks, and streaming services. In 2016, the FCC adopted rules requiring broadband providers to get explicit permission from consumers before using their sensitive personal data for purposes other than providing broadband. Advocates for repealing those protections argue that they create consumer confusion by establishing two sets of rules, one for broadband providers, set by the FCC, and another for online products and services, policed by the FTC. See Terrell McSweeny and Mignon Clyburn, "The Commissioners of the FTC and FCC Are Worried About your Online Privacy," Los Angeles Times, March 31, 2017, http://beta.latimes.com/opinion/op-ed/la-oe-mcsweeny-clyburn-internetprivacy-20170331-story.html.

53 See Kevin Granville, "Facebook and Cambridge Analytica: What You Need to Know as Fallout Widens," New York Times, March 19, 2018, https://www. nytimes.com/2018/03/19/technology/facebook-cambridge-analytica-explained. html.

54 We are not advocating for regulating the city; however, the Internet, similar to water, energy, or telecommunications, is a public utility, and should be regulated as such. See Cecilia Kang, "Court Backs Rules Treating Internet as Utility, not Luxury,” New York Times, June 14, 2016, https://www.nytimes.com/2016/06/15/ technology/net-neutrality-fcc-appeals-court-ruling.html.

55 Also known as scientific rationalism.

56 Henri Lefebvre, Le droit à la ville (1968; repr., Paris: Anthropos, 1996), 178. 
57 Martin Hajer and Arnold Reijndorp, The City Inside Out, Part One: New Public Domains (Amsterdam: NAi Publishers, 2002), 20-22, https://kull28.files. wordpress.com/2014/02/fun-city.pdf. Michail Galanakis discusses a similar concept in the chapter "Staging Spontaneity," in his book Space Unjust: Socio-Spatial Discrimination-Cases from Helsinki and Athens (Jyvaskyla, Finland: Gummerus Printing, 2008), 302-4, accessed January 30, 2019, https:// www.researchgate.net/publication/259579870_Space_Unjust_Socio-Spatial_ Discrimination_in_Urban_Public_Space_-_Cases_from_Helsinki_and_Athens.

58 Simon, "Google Is Building."

59 Jonathan Beard, a longtime community developer at the Columbus Compact Corporation, "sees a bait-and-switch approach-Columbus has a history of using social equity as a guise to obtain government funding, without fulfilling its promises to low income residents. By Columbus' own admission, those opportunities haven't reached poor, predominantly African American neighborhoods such as South Linden." Laura Bliss, "Who Wins When a City Gets Smart?" CityLab, November 1, 2017, accessed January 30, 2019, https:// www.citylab.com/transportation/2017/11/when-a-smart-city-doesnt-have-allthe-answers/542976.

60 Charles Arthur, "Google Facing Legal Threat From Six European Countries Over Privacy," The Guardian, April 2, 2013, https://www.theguardian.com/ technology/2013/apr/02/google-privacy-policy-legal-threat-europe.

61 Bratton, The Stack, 9.

\section{Bibliography}

Arthur, Charles. "Google Facing Legal Threat from Six European Countries Over Privacy." The Guardian, April 2, 2013. https://www.theguardian.com/ technology/2013/apr/02/google-privacy-policy-legal-threat-europe.

Austen, Ian. "City of the Future?" New York Times, December 29, 2017.

https://www.nytimes.com/2017/12/29/world/canada/google-toronto-city-future.html.

Bliss, Laura. "Who Wins When a City Gets Smart?" CityLab, November 1, 2017. https://www.citylab.com/transportation/2017/11/when-a-smart-city-doesnt-have-allthe-answers/542976/.

Bratton, Benjamin. The Stack: On Software and Sovereignty. Cambridge, MA: MIT Press, 2016.

Canada 24 News. "Toronto Must Share the Sidewalk Equitably." October 22, 2017. http://www.canada24news.com/opinion/toronto-must-share-the-sidewalkequitably/33130-news.

Doctoroff, Daniel. "Reimagining Cities from the Internet Up." Medium, November 30, 2016. https://medium.com/sidewalk-talk/reimagining-cities-from-the-internetup-5923d6be63ba.

Easterling, Keller. Extrastatecraft: The Power of Infrastructure Space. London: Verso, 2014.

Ferranato, Priscilla, and T. F. Tierney. "Civic Data and Citizenship in Midwest Urban Contexts." Unpublished paper. 


\section{Amps}

Foster, Mark S. "The Automobile in the Urban Environment: Planning for an EnergyShort Future." The Public Historian 3, no. 4 (1981): 23-31. https://www.jstor.org/ stable/3376842.

Fresh Air. "Why Your Cellphone Could be Called a 'Tracker'." September 6, 2012. https://www.npr.org/2012/09/06/160627856/why-your-cell-phone-could-be-called-atracker.

Galloway, Scott. The Four: The Hidden DNA of Amazon, Apple, Facebook, and Google. New York: Penguin, 2017.

Graham, Stephen, and Simon Marvin. Splintering Urbanism: Networked Infrastructures, Technological Mobilities and the Urban Condition. London: Routledge, 2001.

Greenfield, Adam. Radical Technologies: Software and Everyday Life. London: Verso, 2017.

Gubbi, Jayavardhana, Rajkumar Buyya, Slaven Marusic, and Marimuthu Palaniswami. "Internet of Things (IoT): A Vision, Architectural Elements, and Future Directions." Future Generation Computer Systems 29, no. 7 (2013): 1645-60.

Harari, Yuval Nova. "Dataism Is Our New God.” New Perspectives Quarterly 34, no. 2 (2017): 36-43. https://onlinelibrary.wiley.com/doi/10.1111/npqu.12080.

Kang, Cecilia. "Court Backs Rules Treating Internet as Utility, not Luxury." New York Times, June 14, 2016. https://www.nytimes.com/2016/06/15/technology/netneutrality-fcc-appeals-court-ruling.html.

Kitchen, Rob, and Martin Dodge. Code/Space: Software and Everyday Life. Cambridge, MA: MIT Press, 2011.

Lefebvre, Henri. Critique of Everyday Life, Volume 1: Introduction. London: Verso, 1991. Lefebvre, Henri. Le droit à la ville. Paris: Anthropos, 1996.

MacFarlane, Greg. "How Does Google Make Its Money?" Investopedia, November 12, 2012. https://www.scribd.com/document/317798067/How-Does-Google-MakeIts-Money-docx.

Mattern, Shannon. "The City Is Not a Computer." Places, February 2017. https:// placesjournal.org/article/a-city-is-not-a-computer/. Accessed January 31, 2019.

Mattern, Shannon. "Databodies in Codespace." Places, April 2018. https:// placesjournal.org/article/databodies-in-codespace/. Accessed January 31, 2019.

McGeehan, Patrick. "Free WiFi Kiosks Were to Aid New Yorkers: An Unsavory Side Has Spurred a Retreat." New York Times, September 14, 2016. https://www.nytimes. com/2016/09/15/nyregion/internet-browsers-to-be-disabled-on-new-yorks-free-wifi-kiosks.html.

McSweeny, Terrell, and Mignon Clyburn. "The Commissioners of the FTC and FCC Are Worried About Your Online Privacy." Los Angeles Times, March 31, 2017. http://beta.latimes.com/opinion/op-ed/la-oe-mcsweeny-clyburn-internet-privacy20170331-story.html.

O'Connell, Pamela Licalizi. "Korea's High-Tech Utopia: Where Everything is Observed." New York Times, October 5, 2005. https://www.nytimes.com/2005/10/05/ technology/techspecial/koreas-hightech-utopia-where-everything-is-observed.html.

Peppet, Scott. "Regulating the Internet of Things: First Steps Toward Managing Discrimination, Privacy, Security, and Consent." Texas Law Review 93, no. 1 (2014): 85-176. 


\section{Amps}

Sassen, Saskia. The Global City: New York, London, Tokyo. Princeton, NJ: Princeton University Press, 2001.

Sassen, Saskia. Territory, Authority, Rights: From Medieval to Global Assemblages. Princeton, NJ: Princeton University Press, 2008.

Stadler, Felix. "Between Democracy and Spectacle: The Front-End and Back-End of the Social Web." In The Social Media Reader, edited by M. Mandiberg, 242-56. New York: New York University Press, 2012.

Tierney, T. F. "Positioning Locative Media: A Critical Urban Intervention." Leonardo: Journal of the International Society for the Arts, Sciences, and Technology 46, no. 3 (2013): 253-57.

Townsend, Anthony. Smart Cities: Big Data Civic Hacking and the Quest for a New Utopia. New York: W. W. Norton, 2013.

Weiser, Mark. "The Computer for the 21st Century." Scientific American 265 (1991): 94-106. doi:10.1038/scientificamerican0991-94.

Yang, Chamee. "The Paradox of Urban Mobility and the Spatialization of Technological Utopia." In Intelligent Infrastructure: Zip Cars, Invisible Networks, and Urban Transformation, edited by T. F. Tierney, 186-208. Charlottesville: University of Virginia Press, 2017. 